\title{
The Role of Immunotherapy in Multiple Myeloma
}

\author{
Mehmet Kocoglu ${ }^{\dagger, *}$ and Ashraf Badros ${ }^{\dagger}$ \\ Received: 11 November 2015; Accepted: 6 January 2016; Published: 14 January 2016 \\ Academic Editors: Ashkan Emadi and Dhimant Desai \\ Marlene and Stewart Greenebaum Cancer Center, University of Maryland Medical Center, Baltimore, MD 21201, \\ USA; abadros@umm.edu \\ * Correspondence: mkocoglu@umm.edu; Tel.: +1-410-328-2567; Fax: +1-410-328-6896 \\ + These authors contributed equally to this work.
}

\begin{abstract}
Multiple myeloma is the second most common hematologic malignancy. The treatment of this disease has changed considerably over the last two decades with the introduction to the clinical practice of novel agents such as proteasome inhibitors and immunomodulatory drugs. Basic research efforts towards better understanding of normal and missing immune surveillence in myeloma have led to development of new strategies and therapies that require the engagement of the immune system. Many of these treatments are under clinical development and have already started providing encouraging results. We, for the second time in the last two decades, are about to witness another shift of the paradigm in the management of this ailment. This review will summarize the major approaches in myeloma immunotherapies.
\end{abstract}

Keywords: myeloma; immunotherapy; vaccines; tumor antigens; antibodies; CAR-T; adoptive cell therapy

\section{Introduction}

Multiple myeloma (MM) is a malignant disease of plasma cells that accounts for about $1 \%$ of new cancers and $10 \%$ of all hematological malignancies. It affects elderly patients with a median age of 67 years at presentation. The introduction of several novel agents and targeted therapies has significantly improved outcomes for patients with MM. Although few remain in long-term remissions, the majority of patients relapse and die from the disease, usually with a resistant clone. Immune therapy, in the context of an allogeneic graft, has for years been considered the only curative approach for the disease. Unfortunately, allografts are associated with high mortality and overall poor quality of life due to the development of graft versus host disease. Several attempts to control the disease using variety of immune modulation have been made. In the following review, we will summarize the current knowledge of the immune dysfunction in $\mathrm{MM}$ and the development of various immune modalities to eradicate the disease. We will review the current uses of immunomodulatory drugs, monoclonal antibodies, various vaccination strategies, autologous activated NK and T cells, engineered $\mathrm{T}$ cells and the evolving role of checkpoint inhibitors.

\section{Immune Dysregulation in Multiple Myeloma}

It is well established today that all MM patients have a pre-existing none-malignant stage known as monoclonal gammopathy of unknown significance (MGUS) [1]. The mechanism of progression is not solely limited to genetic mutations in the plasma cells but to alterations in the marrow microenvironment and more importantly to loss of immune surveillance.

Although myeloma is primarily a disorder of the B cell lineage, the T cell compartment is frequently affected [2]. This defect is characterized by a significant reduction in the absolute number of $\mathrm{CD} 4$ cells whereas the numbers of CD8 lymphocytes remain normal, leading to a decreased CD4/CD8 
ratio [2]. In fact loss of tumor specific T cells of CD4, CD8 and NK T cell subsets is a hallmark for progression from MGUS to MM [3]. The balance between regulatory T cells (Treg) and T helper (Th) 17 cells is essential for maintaining anti-tumor immunity in MM [4]. Tregs play an important role in the preservation of self-tolerance and modulation of overall immune responses against infections and tumor cells. In MM patients, Tregs seem to contribute to myeloma-related immune dysfunction. Th17 cells protect against fungal and parasitic infections and participate in inflammatory reactions and autoimmunity. The interplay of TGF- $\beta$ and IL-6, expressed at high levels in the bone marrow of myeloma patients, may affect generation of Th17 cells both directly or via engagement of other pro-inflammatory cytokines and thereby modulate antitumor immune responses. The balance between Tregs and Th17 cells seems to be skewed towards Th17 cells [5]. This has been affected by IL-6, tipping the balance between reciprocal developmental pathways of Tregs and Th17s towards Th17 route [6]. The result is significant immune deficiency in MM.

MM immune dysregulation affects other aspects of the immune system as well, directly affecting antigen presentation and up-regulation of inhibitory antigens that promotes immune escape and growth advantage for malignant clones. On the antigen presenting side, elaborate studies on different aspects of dendritic cell (DC) biology have revealed somewhat conflicting results. Some studies have reported defects in peripheral blood DCs such as decreased numbers of circulating peripheral blood monocytes, plasmacytoid DCs (pDCs) and myeloid DCs (mDCs), lower expression levels of both MHC class II (HLA-DR) and costimulatory molecules (CD40, CD80) as well as decreased alloreactivity against lymphocytes particularly in the setting of IL-6 inhibition [7]. Other studies showed phenotypically and functionally quasi-normal DC biology from peripheral blood and marrow of MM patients and suggested a contributory role of tumor microenvironment to the previously described defects. This was suggested by elevated IL-6 and VEGF levels in the bone marrow sera in MM patients which lead to an inhibition of induction and maturation of DCs [8]. It is also intriguing to detect MM specific antibodies against tumor antigens (e.g., SOX2) at higher concentrations in MGUS states compared to MM [5]. The direct effects of alterations of immune system may clinically be observed by increased risk of infections in myeloma patients. Kristinsson et al. have demonstrated via a population based study that the infection risk even at preclinical stage ie MGUS was increased two folds in 5 and 10 year follow up periods including both bacterial and viral infections [9].

\section{Immunotherapy in Multiple Myeloma}

Standard treatments for MM include standard and high-dose chemotherapy, proteasome inhibitors and IMiDS which usually are given in combinations in conjunction with corticosteroids in the absence or presence of stem cell support. These treatments have radically changed the disease history and improved overall response rates and survival. However, the disease remains incurable and relapse is inevitable in majority of patients. Immunotherapy for 30 years, in the form of an allogeneic stem cell transplant (all-SCT), has been the only treatment modality associated with long-term complete remissions and possibly cures in MM [10]. An effect attributed to the "graft-versus-myeloma"; a proof of principle that the immune system can eradicate a malignant clone has unfortunately limited clinical success primarily due to lack of a predictable uniform and potent response as well as to complications of the procedure including high treatment related mortality [11,12].

Several innovative approaches to enhance the immune system to fight MM and stimulate a "host-versus-myeloma" effect that can benefit the majority of MM patients have been explored. In the following paragraphs we will review immunotherapies as a promising strategy in eliminating the malignant clone in MM focusing on three approaches:

(1) Reverse tumor mediated immune paralysis

a Immunomodulatory drugs (e.g., IMiDs). 
b By blocking inhibitory molecules or, alternatively, activating stimulatory molecules, these treatments are intended to enhance pre-existing anti-myeloma immune responses. (e.g., immune checkpoint inhibitors).

c Cytokines (e.g., interferon and GM-CSF, Siltuximab, an anti-IL-6 antibody and ALT-803, an interleukin 15 agonist).

(2) Stimulate myeloma specific immune responses

a MM Vaccines (e.g., dendritic cell based, peptide based antibodies).

b Adoptive T Cell Transfer (focused on genetically modified T cells to target various MM antigens. (e.g., chimeric antigen receptor (CAR) T cells using BCMA and CD-19 or TCR cells engineered to target the NY-ESO-1 antigen).

(3) Selectively eliminate the malignant clone.

a Monoclonal antibodies (e.g., daratumumab, an antibody against CD38 and elotuzumab, an antibody targeting SLAMF7).

\subsection{Immunomodulatory Drugs (IMiDs)}

IMiDs is a class of drugs that directly affect MM cells and bone marrow microenvironment leading to modulation of cytokines, inhibition of angiogenesis, and augmentation of immune effector numbers and function (T-cell, NK-cell, and NK-T). Recently interaction of IMiDs with cereblon, a ubiquitin ligase component responsible for substrate binding was shown to be crucial for direct cytotoxic and immune related effects [13]. T-cell co-stimulation by lenalidomide or pomalidomide is cereblon dependent and employs two downstream transcription factors, Ikaros (IKZF1) and its paralog Aiolos (IKZF3) [13]. Lenalidomide and pomalidomide also inhibit Treg proliferation. In addition to their effects on T cells, IMIDs are shown to augment NK cell antibody-dependent cellular cytotoxicity (ADCC) via increasing NK cell FasL and Granzyme B expressions [14]. These properties make IMiDs perfect companions to the clinical activities of monoclonal antibodies (mAbs) and to the immune based cellular therapies [15]. The synergistic effects of these combinations are discussed in more detail below in the context of each treatment.

\subsection{Vaccination Strategies}

Two separate vaccination approaches have been developed. The first approach is peptide-based vaccines. The pioneer of these approaches, use of idiotype proteins (Id), an attractive concept as it is, did not meet expectations as potential targets possibly secondary to poor immunogenic nature of the protein as well as low expression of these proteins on the plasma cell surface [16]. There have been efforts to increase immunogenicity via the use of keyhole limpet hemocyanin (KLH), granulocyte macrophage colony stimulating factor (GM-CSF), tetanus toxoid fragments and DCs. In the case of idiotypic proteins, a study investigating the benefit of using idiotype pulsed DCs generated from CD34 progenitors showed good tolerability and safety in 11 patients, yet poor biologic response were seen in about half, some with increase in humoral response and even less with T cell activity [17]. Again, a phase II study investigated stimulation of dendritic cells ex vivo with idiotypic proteins (Mylovenge) in a way similar to the FDA approved prostate cancer treatment sipuleucel (Provenge) reported an almost 2 year overall survival benefit yet had study limitations [18]. There are ongoing active Id peptide vaccination trials in various forms such as idiotype pulsed DCs and Id-KLH. (Table 1).

On the other hand, subsequent identification of tumor associated antigens such as MAGE, NY-ESO1, WT-1, RHAMM-R3 and XBP-1 and their use as targets was able to generate cellular responses when used individually and/or in combination in preclinical studies. Clinically, initial results using a single peptide based vaccine demonstrated that such vaccines can be used with few adverse effects and can elicit immune responses but with modest effect on disease control [19]. Particularly there is a focus on cocktail of fragments of peptides that have abundant expression on myeloma cells. In a 
preclinical study that uses $\mathrm{T}$ cells from myeloma patients, peptide specific cytotoxic $\mathrm{T}$ lymphocytes were successfully generated using XBP-1, CD138 and CS1 as immunogens [20]. This was more recently replicated using cells from smoldering myeloma patients which also showed an enrichment in the effector memory CD8 T cell subset suggesting potentially durable responses [21]. Currently active peptide vaccination trials in myeloma include WT1, hTERT, MAGE-A3 with NY-ESO-1, MAGE-A3 with AS15 and MUC1 (Table 1). Efforts to enhance the immunogenicity of these vaccines, attempted combination with $\mathrm{T}$ cell therapy (see below), although there were impressive immune responses the clinical outcome was lacking.

Table 1. Selected tumor associated antigen targets under clinical trials.

\begin{tabular}{|c|c|c|c|c|c|}
\hline Setting & TAA Target & $\begin{array}{l}\text { Platform/Adjunct } \\
\text { Treatment }\end{array}$ & Phase & Status & Identifier \\
\hline MM (ISS I,II,III) & WT1 & ASCT & \multirow{2}{*}{$\begin{array}{c}\text { Not } \\
\text { provided } \\
\text { I/II }\end{array}$} & $\mathrm{R}$ & NCT01827137 \\
\hline Advanced myeloma & hTERT & ASCT & & $\mathrm{U}$ & NCT00834665 \\
\hline High risk myeloma & $\begin{array}{l}\text { MAGE-A3 and } \\
\text { NY-ESO-1 }\end{array}$ & \multirow{2}{*}{$\begin{array}{l}\text { DTPACE with ASCT } \\
\text { Resiquimod and/or } \\
\text { Poly-ICLC }\end{array}$} & II/III & $\mathrm{C}$ & NCT00090493 \\
\hline Various malignancies & NY-ESO-1 & & $\mathrm{I} / \mathrm{II}$ & $\mathrm{C}$ & NCT00948961 \\
\hline $\begin{array}{c}\text { Symptomatic ISS stage I,II,III } \\
\text { myeloma }\end{array}$ & $\begin{array}{l}\text { MAGE-A3 and } \\
\text { AS15 }\end{array}$ & \multirow{6}{*}{$\begin{array}{c}\text { After ASCT } \\
\text { n/a } \\
\text { Tandem auto/allo SCT } \\
\text { CD3/CD28 activated T } \\
\text { cells ASCT } \\
\text { GM-CSF } \\
\text { hGM-CSF }\end{array}$} & I & ONR & NCT01380145 \\
\hline Early stage (ISS-I) myeloma & Id (DC based ) & & I & $\mathrm{C}$ & NCT00988312 \\
\hline Late stage (ISS-II,III) myeloma & Id pulsed DC & & $\mathrm{I} / \mathrm{II}$ & $\mathrm{C}$ & NCT00186316 \\
\hline $\mathrm{MM}>12$ months of therapy & Id-KLH & & II & $\mathrm{R}$ & NCT01426828 \\
\hline $\mathrm{MM}$ & MUC1 & & II & W & NCT00162500 \\
\hline Various malignancies & MUC1 & & $\mathrm{I} / \mathrm{II}$ & $\mathrm{C}$ & NCT01232712 \\
\hline
\end{tabular}

TAA: Tumor associated antigen; ASCT: Autologous stem cell transplantation; R: Recruiting; U: Unknown;

C: Completed; ONR: Ongoing, not recruiting; W: Withdrawn prior to enrollment; $\mathrm{n} / \mathrm{a}$ : not applicable.

The second vaccination approach involves dendritic cell/myeloma cell fusion (DC/MM). This strategy takes advantage of the ability of the DC to present several antigens from the cell to the host [22]. DC/MM fusions were evaluated in a phase I/II clinical trials [23,24]. In both studies vaccination with DC/MM fusions were well tolerated and stimulated tumor specific immunity as evidenced by expansion of tumor reactive CD4 and CD8 T cells and induction of tumor specific antibody responses. In the second trial, infusion of DC/MM cells on day 100 after transplant was associated with depletion of regulatory $\mathrm{T}$ cells. Interestingly, a quarter of patients with partial response (PR) converted to complete response (CR) after vaccination suggesting that vaccine induced immune responses eliminated minimal residual disease (MRD) [24]. This phase II study is the bases of the ongoing (CTN 1401) trial.

\subsection{Antibody Therapies}

The development of effective cytotoxic $\mathrm{mAb}$ therapies in MM has been hindered by the lack of distinctively and constitutively expressed target molecules on malignant plasma cells. Studies early after the turn of millennium demonstrated only minimal activity of anti-CD20 rituximab which is expressed on $20 \%$ of plasma cells. This was followed by several mAbs (against CD40, IGF-1R, CD56, CS1, CD138, CD74, IL-6R, CD38, TRAIL-R1). For the purpose of this review we will focus on $2 \mathrm{mAbs}$ that have already demonstrated promising clinical activity in MM.

\subsubsection{Elotuzumab; Anti-CS1 (SLAMF7) Antibody}

CS-1 is a transmembrane glycoprotein expressed on normal and malignant plasma cell membranes as well as on NK cells [25]. An IgG1 antibody targeting CS1, elotuzumab, has shown impressive in vitro activity against myeloma cells, killing myeloma cells via antibody dependent cellular cytotoxicity (ADCC) while using the same receptor for activation of NK cells [25,26]. This antibody does not have complement dependent cytotoxicity (CDC) [27]. The initial single agent phase I trial showed no clinical activity in a heavily pre-treated population [28], however, in conjunction with revlimid and 
dexamethasone, elotuzumab had an impressive $82 \%$ objective clinical response in relapsed patients after a median of three lines of prior treatment; median time to progression was still not reached after 16.4 months of follow-up [29]. Recently, a large phase III study (ELOQUENT-2) involving 600 relapsed MM patients confirmed the efficacy of the combination of elotuzumab plus lenalidomide and dexamethasone compared to lenalidomide and dexamethasone alone; progression free survival was $68 \%$ and $41 \%$ at 1 and 2 years (compared to $57 \%$ and $27 \%$ in controls) [30]. Interestingly, elotuzumab also showed activity against disease with high risk cytogenetic features such as $t(4 ; 14)$ and del(17p) as well as, to a lesser extent, +1 q21 [30]. It is also important to note that even though prior treatment with lenalidomide was allowed in this study, only $10 \%$ of the enrolled population had previously been treated with lenalidomide. Combination trials with proteasome inhibitors showed promising results as well, albeit to a lesser degree. Several phase I studies are underway exploring roles of elotuzumab along with anti-KIR antibodies (lirilumab-BMS-986015) or anti-CD137 (urelumab—BMS 663513).

\subsubsection{Daratumumab; Anti-CD38 Antibody}

CD38 is a type II transmembrane glycoprotein with multiple proposed functions in cell adhesion, signaling and enzymatic (cellular nucleic acid metabolism) activity and is expressed on a multiple hematopoietic and non-hematopoietic cell types. Among many hematopoietic cells that harbor this antigen are medullary thymocytes, subpopulations of both activated B and T lymphocytes, NK cells and dendritic cells [31]. Daratumumab is a fully human IgG1 $\mathrm{\kappa}$ monoclonal antibody directed against CD38, that has shown activity against myeloma cells in preclinical models. Among the proposed mechanisms of action of daratumumab, in addition to well described CDC and ADCC are antibody dependent phagocytosis (ADCP), induction of autophagy/apoptosis as well as loss of enzymatic activity (Figure 1).

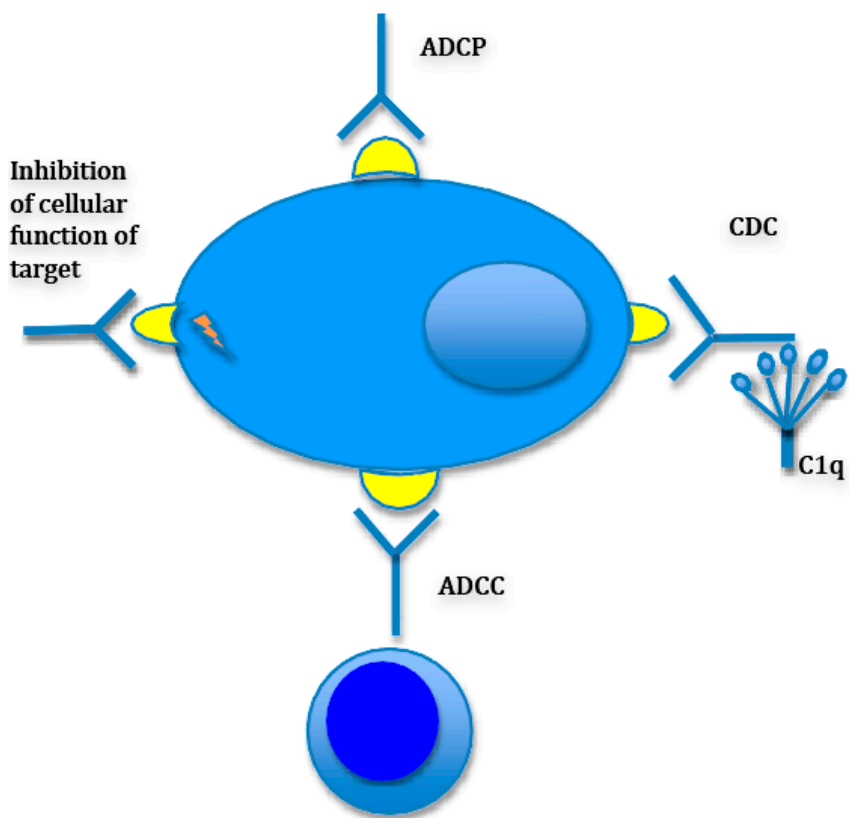

Figure 1. Mechanisms of antibody-mediated myeloma cell killing. Antibodies kill myeloma cells via different mechanisms, some more contributory to the killing effect than the others. There is also variability between antibodies with regards to mechanisms. For instance, while daratumumab was shown to possess all the above mechanisms of action while anti-CS1 antibody elotuzumab is devoid of CDC function. (ADCC: Antibody dependent cellular cytotoxicity; CDC: Complement dependent cytotoxicity; ADCP: Antibody dependent cellular phagocytotoxicity). 
In phase I/II study recently published by Lokhorst et al., impressive clinical responses were seen in heavily pretreated patient population with $64 \%$ double refractory to PIs and IMiDs and had undergone ASCT in $76 \%$ [32]. Daratumumab as a single agent yielded $36 \%$ overall response rate in $16 \mathrm{mg} / \mathrm{kg}$ arm and remarkably, in the responder group, 65\% remained progression free in 12 months.

Two additional antibodies that target CD38 are SAR650984 (isatuximab) and MOR03087 (MOR202; MOR) which are under clinical development as monotherapy or in various combinations.

Several new $\mathrm{mAbs}$ are under development for various cell member targets and others are in early stages but few are worth mentioning. The first is B cell maturation antigen (BCMA), a protein of TNF receptor superfamily which is crucial for long term survival of plasma cells through its binding $B$ cell activating (BAFF) and proliferating (APRIL) factors [33]. Several studies assessing $\mathrm{mAb}$ against BCMA and antibody drug conjugates are underway. Antibodies against CD138 (syndecan) seems limited by the soluble forms of $\mathrm{CD} 138$, however when an $\mathrm{mAb}$ is combined with tubulin polymerization inhibitor maytansinoids, there were significant preclinical as well as early clinical activities in phase I trial [34]. Antibodies targeting CD56 and CD74 are in early stages of clinical development.

\subsubsection{Bispecific T Cell Engagers (BiTEs)}

A new area of antibody research has recently focused on bispecific $T$ cell engagers (BiTEs) that combine specificities of two antibodies by simultaneous binding to multiple epitopes, one of which involves the engagement and activation of $\mathrm{T}$ cells via their CD3 molecules [35] The first bispecific antibody generated specifically against myeloma was developed by combining single-chain variable fragments $(\mathrm{ScFv})$ of a mAb that binds normal and malignant plasma cells (Wue-1) and a mAb against CD3, forming BiTE product (bscWue-1 $\times$ CD3) [36-38]. This led to design and development of other BiTEs. A promising bispecific engager that is currently under clinical investigation targets BCMA via a defucosylated antibody (with the goal of increased binding to Fc receptors) that is conjugated to the monomethyl aurastatin F (MMAF, GSK2857916). This antibody is currently being investigated in a Phase I open-label dose escalation study in relapsed/refractory setting of which clinical outcomes are eagerly awaited. (NCT02064387) [39].

\subsection{Immune Checkpoint Inhibitors (PD-1/PD-L1 Axis)}

Immune checkpoint inhibitors targeting PD-1 (pidilizumab, pembrolizumab and nivolumab) on $\mathrm{T}$ cells or its cognate ligand, PD-L1 on tumor cells have established activities in many different types of cancers [40]. Whereas the initial postulated mechanism of action of the checkpoint blockade was primarily via the engagement of $\mathrm{T}$ cells that are being regulated by peripheral tolerance, a growing body of evidence suggests important roles of antigen presenting cells and activation of NK cells [41]. The preliminary results of a Phase I study with nivolumab that enrolled multiple hematologic malignancies reported disappointing results with no objective responses according to IMWG criteria in 27 myeloma patients, however $67 \%$ of patients remained in stable disease in a population of which two thirds of MM patients were heavily pretreated with more than 3 lines of treatment [42]. Another PD-1 antibody, pidilizumab (CT-011) was investigated via a phase I trial that enrolled 17 patients with various hematological malignancies and has yielded stable disease in the single myeloma patient in the cohort, however, with a durable response for $>13$ months [43]. There are also clinical studies looking into safety and efficacy of pembrolizumab, primarily in combination with IMiDs. Recently, preliminary results of a phase II trial with pembrolizumab with pomalidomide was presented and reported $50 \%$ objective response, including near complete and very good partial responses in a double refractory RRMM patient population [44]. Currently there are several clinical studies investigating the use of immune checkpoint inhibitors in various combinations in MM, majority being PD-1 trials. (Table 2) In addition, there is a growing interest in its cognate molecule, PD-L1 as this is the part of the signaling pathway that is harbored on the tumor itself and at least in theory has the additional potential for ADCC. This ligand was shown to be expressed on malignant plasma cells [45]. In addition, PD-L is also expressed on other cells as well such as on plasmacytoid DCs (pDC) and myeloid derived 
suppressor cells (MDSC) both of which play role in immunosuppressive state in myeloma. The use of PD-L1 antagonists is also being explored in the context of IMiD presence or absence (Table 2).

Table 2. Selected immune checkpoint blockers under clinical trials.

\begin{tabular}{|c|c|c|c|c|c|c|}
\hline Setting & $\begin{array}{c}\text { PD1 } \\
\text { Antibody }\end{array}$ & IMiD & $\begin{array}{l}\text { Additional } \\
\text { Intervention }\end{array}$ & Phase & Status & Identifier \\
\hline NDMM & Pembrolizumab & Lenalidomide & $\mathrm{n} / \mathrm{a}$ & III & $\mathrm{R}$ & NCT02579863 \\
\hline RRMM & Pembrolizumab & Pomalidomide & $\mathrm{n} / \mathrm{a}$ & $\mathrm{I} / \mathrm{II}$ & $\mathrm{R}$ & NCT02289222 \\
\hline RRMM & Pembrolizumab & Pomalidomide & $\mathrm{n} / \mathrm{a}$ & III & $\mathrm{R}$ & NCT02576977 \\
\hline RRMM & Pidilizumab & Lenalidomide & $\mathrm{n} / \mathrm{a}$ & $\mathrm{I} / \mathrm{II}$ & $\mathrm{R}$ & NCT02077959 \\
\hline RRMM & Nivolumab & $\mathrm{n} / \mathrm{a}$ & $\begin{array}{l}\text { Ipilimumab } \\
\text { Lirilumab }\end{array}$ & I & $\mathrm{R}$ & NCT01592370 \\
\hline Post ASCT & Pidilizumab & $\mathrm{n} / \mathrm{a}$ & $\mathrm{DC} / \mathrm{MM}$ & II & ONR & NCT01067287 \\
\hline $\begin{array}{c}\text { Locally advanced/metastatic } \\
\text { solid tumors or hematological } \\
\text { malignancies }\end{array}$ & MPDL3280A & $\mathrm{n} / \mathrm{a}$ & $\mathrm{n} / \mathrm{a}$ & I & $\mathrm{R}$ & NCT01375842 \\
\hline
\end{tabular}

NDMM: Newly diagnosed multiple myeloma; RRMM: Relapsed refractory multiple myeloma; ASCT: Autologous stem cell transplantation; R: Recruiting; U: Unknown; C: Completed; ONR: Ongoing, not recruiting; $\mathrm{W}$ : Withdrawn prior to enrollment; $\mathrm{n} / \mathrm{a}$ : not applicable.

\subsection{Adoptive T Cell Therapies (ACT)}

Early studies suggested that early lymphocyte count recovery after auto-SCT correlated with improved disease control $[46,47]$. Several trials involved ex vivo co-stimulation of autologous T-cells via immunomagnetic beads (anti-CD3/CD28 beads) which in the presence of interleukin-2 led to significant activation and expansion of T cells. Infusion of these cells after myeloablative bone marrow conditioning and autologous stem cell transplantation led to early lymphocytosis. In trials using peripheral blood there is no clear evidence for a tumor specific $\mathrm{T}$ cell enhancement effect and no impact on outcome. This was probably related to nonspecific stimulation of the entire $\mathrm{T}$ cell repertoire including regulatory $\mathrm{T}$ cells. However, it was also noted during early trials that vaccination responses were enhanced in patients receiving ex vivo expanded $\mathrm{T}$ cells. This led to a series of trials using various antibodies (Idiotype, MAGE, hTERT, Survivin) all of which were associated with enhanced antibody and cellular immunity against the vaccine. In the MAGE antibody trial, vaccine-specific cytokine-producing $\mathrm{T}$ cells were detected in 19 of 25 patients $(76 \%)$, however, the clinical outcomes were not correlated with the generated immunity [48]. This may be a reflection of the tumor heterogeneity and/or immune escape mechanisms.

Recently, Borrello and colleagues have shown for the first time that expanding the subset of marrow-infiltrating $\mathrm{T}$ lymphocytes (MILs) can led to clinical antitumor immunity [49]. The results are encouraging but experience with ACTs awaits confirmation in a larger trials.

\subsection{Chimeric Antigen Receptor (CAR) T Cells}

Single chimeric antigen receptor T-cell based therapy (CART), represents a huge leap in immune therapy. CART cells, constructed by fusing the single chain variable fragment (scFv) of a monoclonal antibody $(\mathrm{mAb})$ specific for a surface antigen with an intracellular signaling domain have shown activity in several CD-19 related disease. The MHC-independent tumor recognition, in vivo expansion and memory cell generation confers these cells a clear advantage over naked antibodies or adoptively transferred tumor-reactive T cells. A successful example of CD19 targeted CAR-T cell approach was recently published suggesting activity of this therapy [50]. Even though plasma cells do not have a strong CD-19 expression, Garfall et al. have observed a low, nevertheless a more frequent expression than previously reported on malignant plasma cells and targeting this population via the use of CTL019 cells (lentivirus transduced autologous T cells harboring CD3-zeta/CD137 based anti-CD19 chimeric receptor), reported remission in a 43 year old with 9 prior lines of treatment [50]. In 
this report, this therapy was well tolerated without cytokine release syndrome. They report on treating another 9 patients with more than half being in remission [50]. Again, another example of this strategy that employs an ontogenetically later target ie BCMA-directed lentiviral transduced CAR clinical trials, with restricted and consistent expression pattern of the target antigen are encouraging [51]. Additional attempts using other targets in MM have been less successful and have been attributed to the lack of expression of the target antigen on relevant clones and there are yet others not attempted due to low expression. However, as in the case of CD19 directed CARs, there may be a role of this strategy even for weakly expressed antigens or perhaps due to dynamic nature of surface antigen expressions. At the time being, it remains unclear whether simultaneous targeting of multiple antigens (such as CD38, CS1, BCMA, CD138, etc.) will be needed to eliminate the malignant clone.

\subsection{TCR Transgenic T Cells}

Infusion of auto-engineered T cells with affinity enhanced TCR specific for a common peptide shared between two cancer testis antigens (NY-ESO-1 and LAGE-1) in MM was recently reported [52]. Patients needed to have HLA-A2 and their MM cells expressed NY-ESO-1 and/or LAGE-1. A total of 24 patients were treated and at last follow up, eight remained in remission with a median PFS of 19.1 months and median OS of 32 months. The duration of response is reasonable and seems better than would be expected in this population. Initial laboratory data suggest that the infused cells remain functional in the absence of IL-2 and without exhaustion for up to one year. Relapse patients were both antigen negative (indicating mutational change in the target) and positive (probably reflecting $\mathrm{T}$ cell exhaustion). However, as these cells are HLA dependent, this approach has a limited utility compared to CART cells.

\subsection{Cytokines}

\subsubsection{Interleukin-6 (IL-6)}

Interleukin-6 (IL-6) is a cytokine that has long been under spotlight in myeloma since late 80s as a driver for myeloma which raised the question of benefit of targeting this cytokine for theurapeutic purposes [53]. A phase I/II dose escalation study with chimeric monoclonal anti-IL-6 antibody (CLB IL6/8) resulted in a reduction of endogeneous production, an effect that was attributed to the blockage of a positive feedback loop [54]. A phase II randomized, double blind, placebo controlled study where another anti-IL-6 antibody, siltuximab (CNTO 328), in combination with bortezomib, was compared to bortezomib and placebo combination. In this study, addition of siltuximab to bortezomib in RRMM failed to improve PFS or OS [55]. There are multiple other studies looking at different combinations of IL-6 blockade in conjunction with other standards of care such as bortezomib, VD, VRD and VMP (Table 3).

\subsubsection{Interleukin-15 (IL-15)}

Interleukin-15 (IL-15) is a cytokine that has a critical role in CD8 memory cell and NK cell development, proliferation and activation, making it an attractive target. A complex with superagonistic activity against this cytokine, ALT- 803 was recently developed which in preclinical models was able to employ specifically CD8 memory cells [56]. Whereas NK cells are also activated, the anti-myeloma activity was independent of this activation. A phase I/II study looking into the safety and efficacy of ALT-803 in RRMM is currently under investigation whereas another one is exploring its role in the setting of post-allogeneic SCT relapse in hematological malignancies (Table 3). 
Table 3. Selected cytokine blocking drugs under clinical trials.

\begin{tabular}{|c|c|c|c|c|c|c|}
\hline Setting & Cytokine & Inhibitor & $\begin{array}{c}\text { Additional } \\
\text { Intervention }\end{array}$ & Phase & Status & Identifier \\
\hline NDMM & IL-6 & CNTO 328 & $\begin{array}{c}\mathrm{VMP} \\
\text { combination }\end{array}$ & II & C & NCT00911859 \\
\hline $\begin{array}{l}\text { MGUS, SMM, } \\
\text { indolent MM }\end{array}$ & IL-6 & CNTO 328 & $\begin{array}{l}\text { Cardiac } \\
\text { functions }\end{array}$ & I & C & NCT01219010 \\
\hline $\begin{array}{l}\text { High risk } \\
\text { smoldering }\end{array}$ & IL-6 & CNTO 328 & $\mathrm{n} / \mathrm{a}$ & II & ONR & NCT01484275 \\
\hline RRMM & IL-6 & CNTO 328 & VD & III & W & NCT01266811 \\
\hline NDMM & IL-6 & CNTO 328 & VRD & $\mathrm{Ib} / \mathrm{II}$ & $\mathrm{C}$ & NCT01531998 \\
\hline $\begin{array}{c}\text { MM, NHL, } \\
\text { Castleman's disease }\end{array}$ & IL-6 & CNTO 328 & $\mathrm{n} / \mathrm{a}$ & I & C & NCT00412321 \\
\hline RRMM & IL-6 & CNTO 328 & Dexamethasone & II & $\mathrm{C}$ & NCT00402181 \\
\hline RRMM & IL-6 & CNTO 328 & Bortezomib & II & ONR & NCT00401843 \\
\hline RRMM & IL-15 & ALT-803 & $\mathrm{n} / \mathrm{a}$ & $\mathrm{I} / \mathrm{II}$ & $\mathrm{R}$ & NCT02099539 \\
\hline $\begin{array}{l}\text { Post allogeneic stem } \\
\text { cell transplantation }\end{array}$ & IL-15 & ALT-803 & $\mathrm{n} / \mathrm{a}$ & $\mathrm{I} / \mathrm{II}$ & $\mathrm{R}$ & NCT01885897 \\
\hline
\end{tabular}

\section{Future}

Myeloma is a disease which has seen four decades of treatment with alkylating agents and steroids with barely any improvement in response statistics. Following the advances in basic and translational research, introduction of novel agents, particularly combination therapies, improved indicators of quality of life and survival significantly. With a median survival of over 5 years and counting, finally our attentions are turned to different strategies to obtain deeper and more durable remissions by starting treatment at asymptomatic stages and incorporating minimal residual disease (MRD) to IMWG response criteria. However, it is important to realize that even at the MRD stage, one still has about one in $10^{-5}$ malignant plasma cell burden which we are not currently able to treat [57]. It is possible that the aforementioned immune therapies may be the long sought pieces of puzzle. Paved way by the anti-CD20 treatment rituximab, many different monoclonal antibodies have been designed, developed and have already started shifting the paradigm in the treatment of cancers. This is particularly true for myeloma where various immune therapies are being investigated with exciting results. mAbs, vaccines, IMiDs, checkpoint inhibitors, CARTs and TCRs bear great theurapeutic potential to overcome effects of immune suppressive cytokines and accessory cells in the BM microenvironment, restore host CD4, CD8, and NK cell anti-tumor immunity, and improve patient outcome in MM and with their acceptable toxicity profiles are prime candidates for not only the treatment on relapsed refractory patients but also in newly diagnosed and even in preclinical disease.

Conflicts of Interest: The authors declare no conflict of interest.

\section{References}

1. Korde, N.; Kristinsson, S.Y.; Landgren, O. Monoclonal gammopathy of undetermined significance (MGUS) and smoldering multiple myeloma (SMM): Novel biological insights and development of early treatment strategies. Blood 2011, 117, 5573-5581. [CrossRef] [PubMed]

2. Raitakari, M.; Brown, R.D.; Gibson, J.; Joshua, D.E. T cells in myeloma. Hematol. Oncol. 2003, $21,33-42$. [CrossRef] [PubMed]

3. Dhodapkar, M.V.; Krasovsky, J.; Osman, K.; Geller, M.D. Vigorous premalignancy-specific effector T cell response in the bone marrow of patients with monoclonal gammopathy. J. Exp. Med. 2003, 198, 1753-1757. [CrossRef] [PubMed] 
4. Prabhala, R.H.; Pelluru, D.; Fulciniti, M.; Prabhala, H.K.; Nanjappa, P.; Song, W.; Pai, C.; Amin, S.; Tai, Y.T.; Richardson, P.G.; et al. Elevated IL-17 produced by TH17 cells promotes myeloma cell growth and inhibits immune function in multiple myeloma. Blood 2010, 115, 5385-5392. [CrossRef] [PubMed]

5. Noonan, K.; Borrello, I. The immune microenvironment of myeloma. Cancer Microenviron. 2011, 4, 313-323. [CrossRef] [PubMed]

6. Korn, T.; Mitsdoerffer, M.; Croxford, A.L.; Awasthi, A.; Dardalhon, V.A.; Galileos, G.; Vollmar, P.; Stritesky, G.L.; Kaplan, M.H.; Waisman, A.; et al. IL-6 controls Th17 immunity in vivo by inhibiting the conversion of conventional T cells into Foxp3+ regulatory T cells. Proc. Natl. Acad. Sci. USA 2008, 105, 18460-18465. [CrossRef] [PubMed]

7. Ratta, M.; Fagnoni, F.; Curti, A.; Vescovini, R.; Sansoni, P.; Oliviero, B.; Fogli, M.; Ferri, E.; Della Cuna, G.R.; Tura, S.; et al. Dendritic cells are functionally defective in multiple myeloma: The role of interleukin-6. Blood 2002, 100, 230-237. [CrossRef] [PubMed]

8. Hayashi, T.; Hideshima, T.; Akiyama, M.; Raje, N.; Richardson, P.; Chauhan, D.; Anderson, K.C. Ex vivo induction of multiple myeloma-specific cytotoxic T lymphocytes. Blood 2003, 102, 1435-1442. [CrossRef] [PubMed]

9. Kristinsson, S.Y.; Tang, M.; Pfeiffer, R.M.; Bjorkholm, M.; Goldin, L.R.; Blimark, C.; Mellqvist, U.H.; Wahlin, A.; Turesson, I.; Landgren, O. Monoclonal gammopathy of undetermined significance and risk of infections: A population-based study. Haematologica 2012, 97, 854-858. [CrossRef] [PubMed]

10. Huff, C.A.; Fuchs, E.J.; Noga, S.J.; O'Donnell, P.V.; Ambinder, R.F.; Diehl, L.; Borrello, I.; Vogelsang, G.B.; Miller, C.B.; Flinn, I.A.; et al. Long-term follow-up of T cell-depleted allogeneic bone marrow transplantation in refractory multiple myeloma: Importance of allogeneic T cells. Biol. Blood Marrow Transplant. 2003, 9, 312-319. [CrossRef]

11. Tricot, G.; Vesole, D.H.; Jagannath, S.; Hilton, J.; Munshi, N.; Barlogie, B. Graft-versus-myeloma effect: Proof of principle. Blood 1996, 87, 1196-1198. [PubMed]

12. Verdonck, L.F.; Lokhorst, H.M.; Dekker, A.W.; Nieuwenhuis, H.K.; Petersen, E.J. Graft-versus-myeloma effect in two cases. Lancet 1996, 347, 800-801. [CrossRef]

13. Lu, G.; Middleton, R.E.; Sun, H.; Naniong, M.; Ott, C.J.; Mitsiades, C.S.; Wong, K.K.; Bradner, J.E.; Kaelin, W.G., Jr. The myeloma drug lenalidomide promotes the cereblon-dependent destruction of Ikaros proteins. Science 2014, 343, 305-309. [CrossRef] [PubMed]

14. Quach, H.; Ritchie, D.; Stewart, A.K.; Neeson, P.; Harrison, S.; Smyth, M.J.; Prince, H.M. Mechanism of action of immunomodulatory drugs (IMiDS) in multiple myeloma. Leukemia 2010, 24, 22-32. [CrossRef] [PubMed]

15. Galustian, C.; Meyer, B.; Labarthe, M.C.; Dredge, K.; Klaschka, D.; Henry, J.; Todryk, S.; Chen, R.; Muller, G.; Stirling, D.; et al. The anti-cancer agents lenalidomide and pomalidomide inhibit the proliferation and function of T regulatory cells. Cancer Immunol. Immunother. 2009, 58, 1033-1045. [CrossRef] [PubMed]

16. Yi, Q.; Szmania, S.; Freeman, J.; Qian, J.; Rosen, N.A.; Viswamitra, S.; Cottler-Fox, M.; Barlogie, B.; Tricot, G.; van Rhee, F. Optimizing dendritic cell-based immunotherapy in multiple myeloma: Intranodal injections of idiotype-pulsed CD40 ligand-matured vaccines led to induction of type- 1 and cytotoxic T-cell immune responses in patients. Br. J. Haematol. 2010, 150, 554-564. [CrossRef] [PubMed]

17. Titzer, S.; Christensen, O.; Manzke, O.; Tesch, H.; Wolf, J.; Emmerich, B.; Carsten, C.; Diehl, V.; Bohlen, H. Vaccination of multiple myeloma patients with idiotype-pulsed dendritic cells: Immunological and clinical aspects. Br. J. Haematol. 2000, 108, 805-816. [CrossRef] [PubMed]

18. Lacy, M.Q.; Mandrekar, S.; Dispenzieri, A.; Hayman, S.; Kumar, S.; Buadi, F.; Dingli, D.; Litzow, M.; Wettstein, P.; Padley, D.; et al. Idiotype-pulsed antigen-presenting cells following autologous transplantation for multiple myeloma may be associated with prolonged survival. Am. J. Hematol. 2009, 84, 799-802. [CrossRef] [PubMed]

19. Galluzzi, L.; Vacchelli, E.; Bravo-San Pedro, J.M.; Buque, A.; Senovilla, L.; Baracco, E.E.; Bloy, N.; Castoldi, F.; Abastado, J.P.; Agostinis, P.; et al. Classification of current anticancer immunotherapies. Oncotarget 2014, 5, 12472-12508. [CrossRef] [PubMed]

20. Bae, J.; Smith, R.; Daley, J.; Mimura, N.; Tai, Y.T.; Anderson, K.C.; Munshi, N.C. Myeloma-specific multiple peptides able to generate cytotoxic T lymphocytes: A potential therapeutic application in multiple myeloma and other plasma cell disorders. Clin. Cancer Res. 2012, 18, 4850-4860. [CrossRef] [PubMed] 
21. Bae, J.; Prabhala, R.; Voskertchian, A.; Brown, A.; Maguire, C.; Richardson, P.; Dranoff, G.; Anderson, K.C.; Munshi, N.C. A multiepitope of XBP1, CD138 and CS1 peptides induces myeloma-specific cytotoxic T lymphocytes in T cells of smoldering myeloma patients. Leukemia 2015, 29, 218-229. [CrossRef] [PubMed]

22. Vasir, B.; Borges, V.; Wu, Z.; Grosman, D.; Rosenblatt, J.; Irie, M.; Anderson, K.; Kufe, D.; Avigan, D. Fusion of dendritic cells with multiple myeloma cells results in maturation and enhanced antigen presentation. Br. J. Haematol. 2005, 129, 687-700. [CrossRef] [PubMed]

23. Rosenblatt, J.; Vasir, B.; Uhl, L.; Blotta, S.; Macnamara, C.; Somaiya, P.; Wu, Z.; Joyce, R.; Levine, J.D.; Dombagoda, D.; et al. Vaccination with dendritic cell/tumor fusion cells results in cellular and humoral antitumor immune responses in patients with multiple myeloma. Blood 2011, 117, 393-402. [CrossRef] [PubMed]

24. Rosenblatt, J.; Avivi, I.; Vasir, B.; Uhl, L.; Munshi, N.C.; Katz, T.; Dey, B.R.; Somaiya, P.; Mills, H.; Campigotto, F.; et al. Vaccination with dendritic cell/tumor fusions following autologous stem cell transplant induces immunologic and clinical responses in multiple myeloma patients. Clin. Cancer Res. 2013, 19, 3640-3648. [CrossRef] [PubMed]

25. Hsi, E.D.; Steinle, R.; Balasa, B.; Szmania, S.; Draksharapu, A.; Shum, B.P.; Huseni, M.; Powers, D.; Nanisetti, A.; Zhang, Y.; et al. CS1, a potential new therapeutic antibody target for the treatment of multiple myeloma. Clin. Cancer Res. 2008, 14, 2775-2784. [CrossRef] [PubMed]

26. Collins, S.M.; Bakan, C.E.; Swartzel, G.D.; Hofmeister, C.C.; Efebera, Y.A.; Kwon, H.; Starling, G.C.; Ciarlariello, D.; Bhaskar, S.; Briercheck, E.L.; et al. Elotuzumab directly enhances NK cell cytotoxicity against myeloma via CS1 ligation: Evidence for augmented NK cell function complementing ADCC. Cancer Immunol. Immunother. 2013, 62, 1841-1849. [CrossRef] [PubMed]

27. Tai, Y.T.; Dillon, M.; Song, W.; Leiba, M.; Li, X.F.; Burger, P.; Lee, A.I.; Podar, K.; Hideshima, T.; Rice, A.G.; et al. Anti-CS1 humanized monoclonal antibody HuLuc63 inhibits myeloma cell adhesion and induces antibody-dependent cellular cytotoxicity in the bone marrow milieu. Blood 2008, 112, 1329-1337. [CrossRef] [PubMed]

28. Zonder, J.A.; Mohrbacher, A.F.; Singhal, S.; van Rhee, F.; Bensinger, W.I.; Ding, H.; Fry, J.; Afar, D.E.; Singhal, A.K. A phase 1, multicenter, open-label, dose escalation study of elotuzumab in patients with advanced multiple myeloma. Blood 2012, 120, 552-559. [CrossRef] [PubMed]

29. Lonial, S.; Vij, R.; Harousseau, J.L.; Facon, T.; Moreau, P.; Mazumder, A.; Kaufman, J.L.; Leleu, X.; Tsao, L.C.; Westland, C.; et al. Elotuzumab in combination with lenalidomide and low-dose dexamethasone in relapsed or refractory multiple myeloma. J. Clin. Oncol. 2012, 30, 1953-1959. [CrossRef] [PubMed]

30. Lonial, S.; Dimopoulos, M.; Palumbo, A.; White, D.; Grosicki, S.; Spicka, I.; Walter-Croneck, A.; Moreau, P.; Mateos, M.V.; Magen, H.; et al. ELOQUENT-2 Investigators Elotuzumab Therapy for Relapsed or Refractory Multiple Myeloma. N. Engl. J. Med. 2015, 373, 621-631. [CrossRef] [PubMed]

31. De Weers, M.; Tai, Y.T.; van der Veer, M.S.; Bakker, J.M.; Vink, T.; Jacobs, D.C.; Oomen, L.A.; Peipp, M.; Valerius, T.; Slootstra, J.W.; et al. Daratumumab, a novel therapeutic human CD38 monoclonal antibody, induces killing of multiple myeloma and other hematological tumors. J. Immunol. 2011, 186, 1840-1848. [CrossRef] [PubMed]

32. Lokhorst, H.M.; Plesner, T.; Laubach, J.P.; Nahi, H.; Gimsing, P.; Hansson, M.; Minnema, M.C.; Lassen, U.; Krejcik, J.; Palumbo, A.; et al. Targeting CD38 with daratumumab monotherapy in multiple myeloma. N. Engl. J. Med. 2015, 373, 1207-1219. [CrossRef] [PubMed]

33. O'Connor, B.P.; Raman, V.S.; Erickson, L.D.; Cook, W.J.; Weaver, L.K.; Ahonen, C.; Lin, L.L.; Mantchev, G.T.; Bram, R.J.; Noelle, R.J. BCMA is essential for the survival of long-lived bone marrow plasma cells. J. Exp. Med. 2004, 199, 91-98. [CrossRef] [PubMed]

34. Tassone, P.; Goldmacher, V.S.; Neri, P.; Gozzini, A.; Shammas, M.A.; Whiteman, K.R.; Hylander-Gans, L.L.; Carrasco, D.R.; Hideshima, T.; Shringarpure, R.; et al. Cytotoxic activity of the maytansinoid immunoconjugate B-B4-DM1 against CD138+ multiple myeloma cells. Blood 2004, 104, 3688-3696. [CrossRef] [PubMed]

35. Kontermann, R.E.; Brinkmann, U. Bispecific antibodies. Drug Discov. Today 2015, 20, 838-847. [CrossRef] [PubMed]

36. Honemann, D.; Kufer, P.; Rimpler, M.M.; Chatterjee, M.; Friedl, S.; Riecher, F.; Bommert, K.; Dorken, B.; Bargou, R.C. A novel recombinant bispecific single-chain antibody, bscWue-1 $\times$ CD3, induces T-cell-mediated cytotoxicity towards human multiple myeloma cells. Leukemia 2004, 18, 636-644. [CrossRef] [PubMed] 
37. Zou, J.; Chen, D.; Zong, Y.; Ye, S.; Tang, J.; Meng, H.; An, G.; Zhang, X.; Yang, L. Immunotherapy based on bispecific T-cell engager with hIgG1 Fc sequence as a new therapeutic strategy in multiple myeloma. Cancer Sci. 2015, 106, 512-521. [CrossRef] [PubMed]

38. Bhutani, D.; Lum, L.G. Activated T cells armed with bispecific antibodies kill tumor targets. Curr. Opin. Hematol. 2015, 22, 476-483. [CrossRef] [PubMed]

39. Tai, Y.T.; Anderson, K.C. Targeting B-cell maturation antigen in multiple myeloma. Immunotherapy 2015, 7, 1187-1199. [CrossRef] [PubMed]

40. Lawrence, M.S.; Stojanov, P.; Polak, P.; Kryukov, G.V.; Cibulskis, K.; Sivachenko, A.; Carter, S.L.; Stewart, C.; Mermel, C.H.; Roberts, S.A.; et al. Mutational heterogeneity in cancer and the search for new cancer-associated genes. Nature 2013, 499, 214-218. [CrossRef] [PubMed]

41. Benson, D.M., Jr.; Bakan, C.E.; Mishra, A.; Hofmeister, C.C.; Efebera, Y.; Becknell, B.; Baiocchi, R.A.; Zhang, J.; Yu, J.; Smith, M.K.; et al. The PD-1/PD-L1 axis modulates the natural killer cell versus multiple myeloma effect: A therapeutic target for CT-011, a novel monoclonal anti-PD-1 antibody. Blood 2010, 116, 2286-2294. [CrossRef] [PubMed]

42. Lesokhin, A.; Ansell, S.; Armand, P.; Scott, E.; Halwani, A.; Gutierrez, M.; Millenson, M.; Cohen, A.; Schuster, S.; Lebovic, D.; et al. Preliminary results of a phase I study of Nivolumab (BMS-936558) in patients with relapsed or refractory lymphoid malignancies. Blood 2014, 124, 291.

43. Berger, R.; Rotem-Yehudar, R.; Slama, G.; Landes, S.; Kneller, A.; Leiba, M.; Koren-Michowitz, M.; Shimoni, A.; Nagler, A. Phase I safety and pharmacokinetic study of CT-011, a humanized antibody interacting with PD-1, in patients with advanced hematologic malignancies. Clin. Cancer Res. 2008, 14, 3044-3051. [CrossRef] [PubMed]

44. Badros, A.; Kocoglu, M.; Ma, N.; Rapoport, A.; Lederer, E.; Philip, S.; Lesho, P.D.C.; Hardy, N.; Yared, J.; Goloubeva, O.; Singh, Z. A phase II study of anti PD-1 antibody pembrolizumab, pomalidomide and dexamethasone in patients with relapsed/refractory multiple myeloma (RRMM). Blood 2015, 126, 506.

45. Yousef, S.; Marvin, J.; Steinbach, M.; Langemo, A.; Kovacsovics, T.; Binder, M.; Kroger, N.; Luetkens, T.; Atanackovic, D. Immunomodulatory molecule PD-L1 is expressed on malignant plasma cells and myeloma-propagating pre-plasma cells in the bone marrow of multiple myeloma patients. Blood Cancer J. 2015, 5, e285. [CrossRef] [PubMed]

46. Raitakari, M.; Brown, R.D.; Sze, D.; Yuen, E.; Barrow, L.; Nelson, M.; Pope, B.; Esdale, W.; Gibson, J.; Joshua, D.E. T-cell expansions in patients with multiple myeloma have a phenotype of cytotoxic T cells. Br. J. Haematol. 2000, 110, 203-209. [CrossRef] [PubMed]

47. Porrata, L.F.; Gertz, M.A.; Inwards, D.J.; Litzow, M.R.; Lacy, M.Q.; Tefferi, A.; Gastineau, D.A.; Dispenzieri, A.; Ansell, S.M.; Micallef, I.N.; et al. Early lymphocyte recovery predicts superior survival after autologous hematopoietic stem cell transplantation in multiple myeloma or non-Hodgkin lymphoma. Blood 2001, 98, 579-585. [CrossRef] [PubMed]

48. Rapoport, A.P.; Aqui, N.A.; Stadtmauer, E.A.; Vogl, D.T.; Xu, Y.Y.; Kalos, M.; Cai, L.; Fang, H.B.; Weiss, B.M.; Badros, A.; et al. Combination immunotherapy after ASCT for multiple myeloma using MAGE-A3/Poly-ICLC immunizations followed by adoptive transfer of vaccine-primed and costimulated autologous T cells. Clin. Cancer Res. 2014, 20, 1355-1365. [CrossRef] [PubMed]

49. Noonan, K.A.; Huff, C.A.; Davis, J.; Lemas, M.V.; Fiorino, S.; Bitzan, J.; Ferguson, A.; Emerling, A.; Luznik, L.; Matsui, W.; et al. Adoptive transfer of activated marrow-infiltrating lymphocytes induces measurable antitumor immunity in the bone marrow in multiple myeloma. Sci. Transl. Med. 2015, 7, 288ra78. [CrossRef] [PubMed]

50. Garfall, A.L.; Maus, M.V.; Hwang, W.T.; Lacey, S.F.; Mahnke, Y.D.; Melenhorst, J.J.; Zheng, Z.; Vogl, D.T.; Cohen, A.D.; Weiss, B.M.; et al. Chimeric antigen receptor T cells against CD19 for multiple myeloma. N. Engl. J. Med. 2015, 373, 1040-1047. [CrossRef] [PubMed]

51. Carpenter, R.O.; Evbuomwan, M.O.; Pittaluga, S.; Rose, J.J.; Raffeld, M.; Yang, S.; Gress, R.E.; Hakim, F.T.; Kochenderfer, J.N. B-cell maturation antigen is a promising target for adoptive T-cell therapy of multiple myeloma. Clin. Cancer Res. 2013, 19, 2048-2060. [CrossRef] [PubMed]

52. Rapoport, A.P.; Stadtmauer, E.A.; Binder-Scholl, G.K.; Goloubeva, O.; Vogl, D.T.; Lacey, S.F.; Badros, A.Z.; Garfall, A.; Weiss, B.; Finklestein, J.; et al. NY-ESO-1-specific TCR-engineered T cells mediate sustained antigen-specific antitumor effects in myeloma. Nat. Med. 2015, 21, 914-921. [CrossRef] [PubMed] 
53. Van Oers, M.H.; van Zaanen, H.C.; Lokhorst, H.M. Interleukin-6, a new target for therapy in multiple myeloma? Ann. Hematol. 1993, 66, 219-223. [CrossRef] [PubMed]

54. Van Zaanen, H.C.; Koopmans, R.P.; Aarden, L.A.; Rensink, H.J.; Stouthard, J.M.; Warnaar, S.O.; Lokhorst, H.M.; van Oers, M.H. Endogenous interleukin 6 production in multiple myeloma patients treated with chimeric monoclonal anti-IL6 antibodies indicates the existence of a positive feed-back loop. J. Clin. Investig. 1996, 98, 1441-1448. [CrossRef] [PubMed]

55. Orlowski, R.Z.; Gercheva, L.; Williams, C.; Sutherland, H.; Robak, T.; Masszi, T.; Goranova-Marinova, V.; Dimopoulos, M.A.; Cavenagh, J.D.; Spicka, I.; et al. A phase 2, randomized, double-blind, placebo-controlled study of siltuximab (anti-IL-6 mAb) and bortezomib versus bortezomib alone in patients with relapsed or refractory multiple myeloma. Am. J. Hematol. 2015, 90, 42-49. [CrossRef] [PubMed]

56. Wong, H.C.; Jeng, E.K.; Rhode, P.R. The IL-15-based superagonist ALT-803 promotes the antigen-independent conversion of memory CD8 T cells into innate-like effector cells with antitumor activity. Oncoimmunology 2013, 2, e26442. [CrossRef] [PubMed]

57. Paiva, B.; van Dongen, J.J.; Orfao, A. New criteria for response assessment: Role of minimal residual disease in multiple myeloma. Blood 2015, 125, 3059-3068. [CrossRef] [PubMed]

(C) 2016 by the authors; licensee MDPI, Basel, Switzerland. This article is an open access article distributed under the terms and conditions of the Creative Commons by Attribution (CC-BY) license (http://creativecommons.org/licenses/by/4.0/). 